\title{
Socio-cultural, Economic, and Environmental Effects of Tourism from the Point of View of the Local Community
}

\author{
Abdullah USLU \\ Manavgat Faculty of Tourism, Akdeniz University, Manavgat/Antalya, Turkey \\ Gürkan ALAGÖZ \\ Vocational School of Tourism and Hotel Management, Erzincan Binali Yıldırım University, Erzincan, Turkey \\ Erkan GÜNEŞ \\ Vocational School of Tourism and Hotel Management, Erzincan Binali Yıldırım University, Erzincan, Turkey
}

Received: 24 February 2020. Revision received: 20 May 2020. Accepted: 30 June 2020.

\begin{abstract}
The purpose of this research is to determine the socio-cultural, economic, and environmental effects of tourism perceived by the local community living in Manavgat/Turkey on the satisfaction with the tourism development, to identify the effect of this satisfaction with tourism development, and to ascertain the moderator role of the demographic variables in this relationship. The population of the research is the local community living in Manavgat/Turkey. EFA, CFA, path analyzes, and Slope difference tests have been performed through 384 surveys collected from the local community. As a result, it has been determined that perceived socio-cultural, economic, and environmental positive effects of tourism and negative environmental effects have an impact on satisfaction with tourism development. Meanwhile, it has been determined that the local community's satisfaction with tourism development affects the attitude and gender has a moderator role on this effect. In line with these results, public institutions, tourism professionals, and non-governmental organizations in Manavgat will be able to better perceive the local community's attitudes and behaviors.
\end{abstract}

Key Words: Local community, Effects of tourism, Demographic Variables, Moderator, Manavgat

JEL Classification: L83, Z32

Reference: Uslu, A., Alagöz, G., Güneş, E. (2020). Socio-cultural, Economic, and Environmental Effects of Tourism from the Point of View of the Local Community. Journal of Tourism and Services, 21(11), 1-21. doi: 10.29036/jots.v11i21.147

\section{Introduction}

The rapid and strong growth of mass tourism since the 1950s has made the tourism sector one of the most important sectors in the world (Almeida-García, 2018; Gozgor \& Demir, 2018). This ongoing global growth results in countries or regions formulating strategic plans, long-term planning, or development trends to maximize their contribution to tourism development (Nematpour \& Faraji, 2019).

Especially in the last two decades, excessive or unplanned development of the tourism sector, which has provided important contributions for local economies such as increasing employment, contributing to the economy, and protecting cultural heritage, may also have negative effects on the local community, resources and socio-cultural structure (Wang et al., 2020). In this context, the effects 


\section{JOURNAL OF TOURISM AND SERVICES}

Issue 21, volume 11, ISSN 1804-5650 (Online)

www.jots.cz

of the tourism industry are among the priority issues during the development of the industry (Nematpour \& Faraji, 2019).

When it comes to tourism development, the life of the local community changes in many ways (Fila et al., 2015). However, the local community must accept this change and continue their lives, but they can be both optimistic and pessimistic in this process. If the future of tourism is perceived as optimistic, residents of the region will interpret tourism development positively, but if they are perceived as inappropriate and inevitable, they will perceive this development as hostile (Lim \& Lee, 2020). Understanding the local community's perspective on tourism development can minimize the negative effects arising from tourism development, while maximizing the benefits, facilitating the development of society and developing policies that contribute more to tourism (Thetsane, 2019).

Factors affecting the support of the local community in tourism development have been extensively researched in the literature. Factors such as community loyalty, personal attitudes, and perceived benefits from tourism can strongly influence local community support (Meyer et al., 2017; Brankov et al., 2019). While Doxey (1975) explains the interaction between local community and tourists in tourism destinations with irritation index and Butler (1980) with destination lifecycle models, they assume that there is a change in the attitudes of the local population, mainly due to the increase in the number of tourists (Szromek et al. 2020). However, Öztürk et al. (2015) have stated that tourism activities have positive economic, environmental and socio-cultural effects along with negative economic, environmental and socio-cultural effects on the host society.

The meaning and intensity of the effects of tourist mobility in a tourism destination may vary depending on the number of tourists and the nature of the destination. The impact can be physical, economic or social, and the local community can add positive or negative meaning to these effects (Anuar et al., 2019). It is important for the tourism development to investigate to what extent the local community are affected by the emerging effects and their satisfaction with tourism development. As a matter of fact, the satisfaction and benefit of local community should be at the forefront in the center of tourism development planning.

There is no clear explanation for how the roles and opinions of local community are involved in the entire tourism planning and development process. Although the literature suggests some roles that local community can take in tourism development, it is stated that little attention is given to how they feel about these imposed roles. This may cause dissatisfaction with the roles of local community in tourism development and contrary to what the literature suggests (Androniceanu \& Tvaronavičiene, 2019). Tourism presents various economic, socio-cultural and environmental effects, some of which are more beneficial than others in the life of the local community (Szczepańska-Woszczyna \& KurowskaPysz, 2016; Thetsane, 2019; Androniceanu, 2019). While these effects create dissatisfaction in one segment, they may cause dissatisfaction in some segments (Dkhili, 2018; Masharsky et al, 2018).

Providing the sustainability of the tourism sector, which has a very fragile structure, in a destination, is related to how many people perceive the economic, socio-cultural and environmental effects that arise from the tourism activities and their satisfaction with this situation. It is not possible to talk about a sustainable tourism development in the destinations where the positive and negative effects arising from the local community and tourism development are not considered (Alaeddinoğlu, 2008). When the negative perception of the local community from the tourism development increases, this will create dissatisfaction among the local community and therefore the attitude towards tourism development will decrease. It is important to determine how economic, socio-cultural and environmental positive and negative effects of tourism are perceived by local community.

The economy of Manavgat is based on agriculture in rural areas and tourism in coastal areas. Tourism has a growing structure in Manavgat. Tourism sector has become one of the main livelihoods of the region, following the agriculture. Manavgat region serves approximately $35 \%$ of the local tourists who come to Antalya, which is one of the destinations in Turkey with the highest tourist attraction (Manavgat Chamber of Commerce and Industry, 2016, p.2). 


\section{JOURNAL OF TOURISM AND SERVICES}

Issue 21, volume 11, ISSN 1804-5650 (Online)

www.jots.cz

Manavgat tourism destination is one of the destinations that comes to the fore in the country tourism with its tourism values. If the positive and negative effects perceived by tourism development and local community in this region are determined correctly, tourism development can evolve to a more sustainable direction. In this context, in the study, it is attempted to determine the effect of positive and negative socio-cultural, economic and environmental effects of tourism perceived by the local community on the satisfaction with the tourism development and the effect of the satisfaction with tourism development on the local community's attitude on the support for tourism development and put forth the moderator role of demographic characteristics in this relationship.

\section{Perception and Attitude of Local Community in Tourism Development}

Tourism, which contributes to countries in different areas such as socializing people, getting to know different cultures, learning new things and gaining many different experiences, contributing to different destinations to destinations and destinations, supporting regional development in different ways, is one of the areas whose effects must be measured. While having positive effects due to its contribution, tourism also has negative effects. In both cases, these effects need to be examined and their consequences addressed to all stakeholders in tourism.

Tourism has many effects that directly affect the local community. Although it is considered that tourism affects local community only socially and culturally in the first place, it has come to the fore in the tourism development that local community should be considered as an important shareholder, especially in planning and sustainable tourism phenomenon (Ayazlar, 2016, p.2538). The tourism phenomenon reveals an interaction that has very different effects. It brings about demographic, economic, cultural and environmental changes socially with the displacement of people. Examples of these changes are population growth in the region, age and gender distribution, changes in consumption patterns and production factors, consumption of culture, differentiation of cultural norms, environmental damage (Tuna, 2007, p.15).

Many academic studies on the effects of local community and tourism have been carried out until today. The effects of tourism are addressed positively and negatively economically, environmentally and socially and culturally. Doxey's (1975) discomfort/tolerance index suggests that communities undergo a series of reactions as the effects of the developing tourism industry in their region become more pronounced and their perceptions change with experience. The stages of Doxey's model are stated as happiness, indifference, anger/irritation, and finally hostility/hatred. There is also a link between Doxey's model and Butler's (1980) tourism area life cycle model that defines a series of stages in the evolution of tourism in a destination. These stages are discovery, participation, development, consolidation, stagnation, decline or revival, respectively. The life cycle of the product specified by Butler (1980) is that, due to the nature of tourism in a region, it is becoming increasingly focused on mass tourism and thus causes negative effects. It is stated that with the weakening of the region's attractiveness over time, the feature of being the tourism center of the region has been affected (Faulkner \& Tideswell, 1997, p.6). Getz (1983), on the other hand, has discussed the different effects of tourism with its physical, economic, perceptual, social, ecological and political carrying capacity dimensions (Kennell, 2016, p.133).

When evaluated within the scope of social change theory, the evaluation of the benefits and losses that it will leave on economic, social and environmental resources in the tourism change process affects the local community's attitude towards tourism. While those who establish a beneficial shopping-based relationship with tourists within the scope of social change theory support tourism, those who perceive shopping as harmful will oppose the tourism development. The benefits that it will leave on social and economic conditions affect the local community's attitude towards tourism (Jurowski et al., 1997, p.4). Karakaş \& Şengün (2017, p.184) have stated that if the benefit of the local 


\section{JOURNAL OF TOURISM AND SERVICES}

Issue 21, volume 11, ISSN 1804-5650 (Online)

www.jots.cz

community with tourism is less than the harm to be caused by the tourism, the attitude of the people towards tourism may turn into a negative. In addition, a similar result has been determined by Türker et al. (2016, p.10). It has been emphasized that the support of local community to tourism may differ according to the economic, social and environmental effects of tourism, and if the perception of the local community is positive, tourism will be supported. In line with all these studies in the literature, the hypotheses $\mathrm{H}_{1}, \mathrm{H}_{3}, \mathrm{H}_{5}$ and $\mathrm{H}_{7}$ have been generated as follows.

$H_{1}$ : The perceived socio-cultural effects of tourism have a significant and positive effect on the satisfaction of the local community towards tourism development.

$H_{3}$ : The perceived economic effects of tourism have a significant and positive effect on the satisfaction of the local community towards tourism development.

$H_{5}$ : The perceived environmental effects of tourism have a significant and positive effect on the satisfaction of the local community towards tourism development.

$H_{7}:$ Satisfaction with tourism development has a significant and positive effect on attitude.

Öztürk et al. (2015, p.234) have stated the positive effects of tourism as increased income, improved standard of living, new job opportunities, new investments, improvement in infrastructure and superstructure in terms of quality and quantity and increase in tax revenues. Meanwhile, they listed the negative effects as an increase in the prices of products, services and real estate, an increase in inflation, dependence on tourism and an increase in imports. In addition to the economic effects mentioned here, Kozak et al. (2015, p.111-121) have listed the benefits of tourism to the positive economic effects, balance of payments, interregional development and other economic sectors, while they pointed out the opportunity cost, the need for foreign labor and seasonal fluctuations to their negative economic effects.

The most important effects of tourism are on the physical environment. The main production factor of tourism, i.e. the source of attraction, is the natural environment. Öztürk et al., (2015, p.234) have stated the positive environmental effects of tourism in the form of environmental awareness and better environmental management, restoration of historical sites and monuments and protection of natural and cultural heritage sites. The negative effects of tourism on the environment are listed as the increase in the consumption of natural resources, the destruction of lands and their use from sustainability, the changes in the eco system caused by tourism enterprises, the increasing pressure on the existing infrastructure and finally the increase in air, water, noise and visual pollution.

Tourism has positive and negative effects on the social and cultural environment. These effects have an important place since tourism is a movement of displacement and it is based on human relations. Öztürk et al. (2015, p.234) has noted the positive socio-cultural effects of tourism as recognizing and experiencing different cultures, contributing to the formation of an international diversity, tolerance and peace environment, recognition and appreciation of new cultural values and traditions and the negative socio-cultural impacts as disruption in the mother tongue, change and assimilation in local identity and values, commodification of culture, loss of originality, disruption of traditional life style and hospitality, social ties and weakening of family ties and cultural conflicts between tourists and local community. In addition, Kozak et al. (2015, p.130-133) have stated that, in addition to positive socio-cultural impacts, tourism contributes to the urbanization of rural areas, advances in women's rights, development of leisure habits, development of cleanliness awareness, promoting language learning, emerging of new professions and institutions, development of consciousness for protecting the local community's cultural values. They emphasized that, in addition to the negative socio-cultural effects, tourism may cause xenophobia and increase the crime rate. Nunkoo \& Ramkissoon (2007, p.141) have stated that the relationship between the tourist and the local community provides opportunities for both parties to get to know each other's culture and can contribute to the positive changes in the attitude of the tourists towards the local community and the 


\section{JOURNAL OF TOURISM AND SERVICES}

Issue 21, volume 11, ISSN 1804-5650 (Online)

www.jots.cz

development of friendship. The positive effects of smart technologies is portrayed by Hecht et al. (2019) underlining their impact on sustainable urban development. In line with this information, it has been stipulated that the socio-cultural, economic and environmental negative effects of tourism perceived by the local community has effects on the satisfaction with the tourism development and the hypotheses $\mathrm{H}_{2}, \mathrm{H}_{4}$ and $\mathrm{H}_{6}$ demonstrated in Figure 1 have been developed as follows.

$\mathrm{H}_{2}$ : The perceived socio-cultural effects of tourism have a significant and negative impact on the satisfaction of the local community towards tourism development.

$\mathrm{H}_{4}$ : The perceived economic effects of tourism have a significant and negative impact on the satisfaction of the local community towards tourism development.

$H_{6}$ : The perceived environmental effects of tourism have a significant and negative impact on the satisfaction of the local community towards tourism development.

\section{Studies on Local Community and Tourism Perception}

Many characteristics of the local community regarding perception of the effects of tourism play an important role. Snaith \& Haley (1999, p.595) have stated that the support provided by the settled population to tourism development differs according to socio-economic and demographic indicators. Tayfun (2002, p.8) has stated that residing in the tourist area in the tourist-local community relationship has changed the perspective towards the tourist positively, while those who do not live in the tourist area do not have an opinion on this issue. Kuvan \& Akan (2005, p.703) have stated that economic, socio-cultural and environmental impacts vary according to socio-demographic characteristics as a result of their research on the impact of tourism on local community and that especially income has an important effect on attitude. It also has an impact on perception when working in a tourism-related job (Horecký \& Blažek, 2019).

Boğan \& Sarışık (2016, p.328) have pointed out that some variables may be important in the perception of tourism. These variables are some of the demographic elements such as the duration of living in the region where tourism develops, the distance between the place of residence and the tourism development region, whether or not it earns from tourism, the location of the destination in the life curve, whether the region is local or not, age, gender, education. As a result of the said research, they stated that the perceptions of the local community towards the effects of tourism differ according to socio-demographic characteristics. Filiz \& Yllmaz (2017, p.1817) have stated that the support given by local community to tourism development varies according to demographic characteristics. The support of people for tourism varies based on gender, age and occupation. Hançer \& Manc1 (2017) have stated that socio-demographic variables are effective in perceiving the effects of tourism. Accordingly, the economic, socio-cultural and environmental effects of tourism vary according to the socio-demographic characteristics of the person such as age, gender, education, occupation, marital status, whether to go on vacation, income, birth place.

Gündüz (2018, p.354) have stated in his research that the perceived negative impact of tourism on the environment varies according to the age variable and that the assessment of environmental destruction varies among professional groups. Güneş \& Alagöz (2018, p.432-436) have noted that the demographic characteristics of the local community affect the perception of tourism. The variables such as education status, occupation, marital status, birth place, whether to go on vacation or not, differentiate the local community's perception of tourism. In addition, according to gender, marital status and whether to go on vacation, the local community's perspectives on the effects of tourism differ. Olcay \& Araboğa (2018, p.955-956) have stated that local community's perspective on tourism varies according to age and marital status. In order to test the information obtained from the literature, the hypotheses $\mathrm{H}_{8}$ shown in Figure 1 have been developed as follows. 


\section{JOURNAL OF TOURISM AND SERVICES}

Issue 21, volume 11, ISSN 1804-5650 (Online)

www.jots.cz

$H_{8}$ : Demographic variables have a moderating effect on the relationship between attitude and satisfaction with tourism development.

$H_{8 a}:$ Gender has a moderating effect on the relationship between satisfaction and attitude towards tourism development.

$H_{8 b}$ : Marital status has a moderating effect on the relationship between satisfaction and attitude towards tourism development.

$H_{8 c}$ : The place of birth has a moderating effect on the relationship between satisfaction with tourism development and attitude.

\section{Methods}

\subsection{Aim, Scope and Method of the Research}

The purpose of this study; is to determine the effect of the perceived socio-cultural, economic and environmental positive and negative effects of the local community living in Manavgat tourism destination on the satisfaction of tourism and to determine the effect of the satisfaction of the local community on the tourism development on the attitude of the local community towards the tourism development and in this relationship between them to determine the moderator effect of demographic variables. Therefore, the model of the research has been created as in Figure 1 by making use of the studies used in the literature (Ko \& Stewart, 2002; Ekici \& Çizel, 2014).

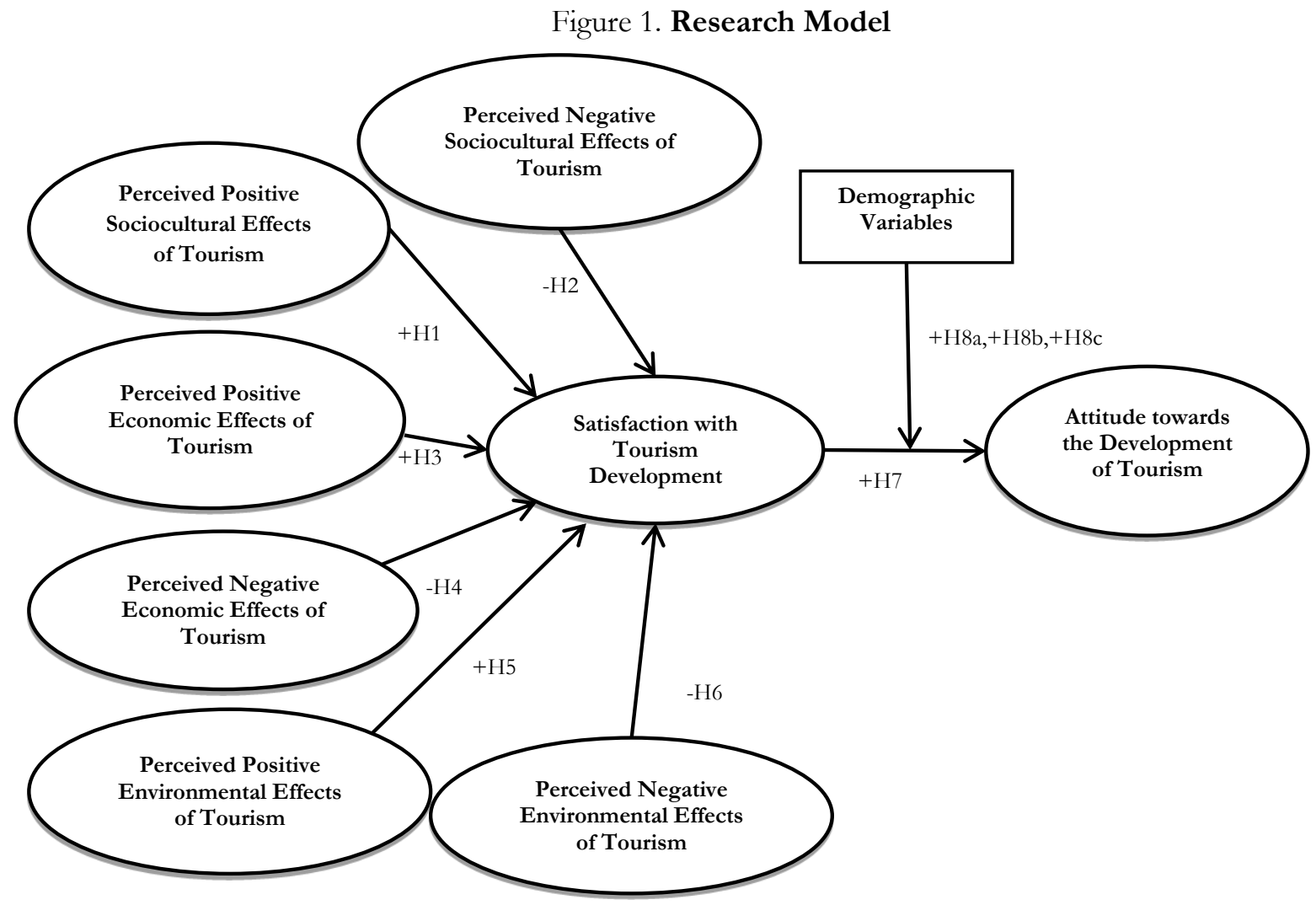

Source: Authors own conception

As an important tourism destination of the Mediterranean that forms the area of the research, Manavgat has the potential to host many types of tourism. Considering the employment structure of Manavgat, it is observed that a large part of the employees is in the services sector and a significant 


\section{JOURNAL OF TOURISM AND SERVICES}

Issue 21, volume 11, ISSN 1804-5650 (Online)

www.jots.cz

share of them in tourism (Ak, 2019, p.90).The population determined for this research is the local community living in Manavgat, an important tourism destination in the province of Antalya. According to 2019 data of Turkish Statistical Institute, 241.011 individuals are living in Manavgat. The sample size that can represent the population has been determined as at least 384 people with $5 \%$ error margin (Yazıcıŏlu \& Erdoğan, 2004). Accordingly, the surveys have been applied to 405 volunteers who have been selected through the easy sampling method in February and March 2019 and who voluntarily participated. The data obtained has been collected as a result of face to face interviews with the survey technique, which is frequently preferred in quantitative research methods. The scales used in the research have been adapted from previous studies. In order to test whether the survey data is reliable or not, a pilot study has been conducted with 40 people living in Manavgat in January 2019. Accordingly, Cronbach's alpha coefficient $(\alpha=0.915)$ of 20 statements to be used in the structural model has been found to be highly reliable and the survey continued.

The survey consists of two sections. In the first sections, there are statements about the demographic characteristics of the local community. In the second section, 24 statements have been taken from the researches by Hong Long (2012) and Andereck \& Vogt (2000) in order to determine the perception of local community towards the effects of tourism, three statements have been taken from the studies by Vargas-Sanchez et al. (2009) in order to measure the local community's satisfaction with tourism development and four statements have been taken from the researches by Andereck \& Vogt (2000), Wang et al. (2006) and Hong Long (2012) in order to determine the attitude towards the support provided for tourism development. These statements in the survey are rated with 5-point Likert scale as $1=$ Completely Disagree; $2=$ Disagree; $3=$ Neither Agree nor Disagree; $4=$ Agree; $5=$ Completely Agree.

While preparing 405 survey data collected from local community for analysis, missing data, extreme values, normality and homogeneity issues have been taken into consideration. 21 surveys with missing data has been excluded from the research due to reasons such as filling incompletely and filling without reading. The study has continued with the remaining 384 survey data. As a result of the homogeneity test, the data has been found to be homogeneous since the $\mathrm{p}$ value is greater than 0.05 (Kalayc1, 2008).

\section{Results}

\subsection{Demographic Features of Local People}

The frequency and percentage distributions of the demographic characteristics of the participants in the study are given in Table 1. According to the table, it has been determined that $63.5 \%$ (244 people) of the participants are male, 36.5\% (140 people) are female, 68.5\% (263 people) are married and 31.5\% (121 people) are single. It has been determined that the average of their ages is 37.69. When the birth places are analyzed, it is observed that the rate of those who are born in Manavgat is $40.6 \%$ (156 people) while the rate of other respondents is $59.4 \%$ (228 people). It is understood that the people who choose the other option are people living in Manavgat and coming from almost all cities, especially near Manavgat. In terms of education, it is understood that those who are undergraduate graduates with a rate of 29.4\% (113 people) and high school graduates with a rate of $29.2 \%$ (112 people) are predominant. Considering the monthly income levels of the participants, it is observed that $27.1 \%$ (104 people) have an income between TRY 2020-3000, 21.6\% (83) between TRY $3001-4000$ and $16.4 \%$ (63 people) have the minimum wage. It is observed that the ones with the lowest monthly income have an income of TRY 5001 and more with a rate of 10.7\% (41 people). When the occupational groups of the participants are examined; it can be observed that $32 \%$ (123 people) are workers and 26.6\% (102 people) are civil servants, and 11.5\% (44 people) are engineers, teachers, 


\section{JOURNAL OF TOURISM AND SERVICES}

Issue 21, volume 11, ISSN 1804-5650 (Online)

www.jots.cz

technicians, nurses who mark the other option. It is observed that $55.5 \%$ (213 people) of the local community do not work in tourism and the remaining 44.5\% (171 people) work in tourism. When the participants evaluated the level of tourism that Manavgat has reached, more than half $(53.4 \%=205$ people) have stated that it is in the development stage and $23.4 \%$ (90 people) in the maturity stage. According to all these results; it is observed that the participants in the survey are mostly middle-aged, married, high school or university education, not working in tourism and have an income of TRY 20203000 .

Table 1. Demographic Characteristics of Local Community

\begin{tabular}{|l|l|l|l|l|l|}
\hline Gender & $\mathbf{n}$ & $\mathbf{\%}$ & Marital Status & $\mathbf{n}$ & $\mathbf{\%}$ \\
\hline Female & 244 & 63.5 & Married & 263 & 68.5 \\
\hline Male & 140 & 36.5 & Single & 121 & 31.5 \\
\hline Education Status & $\mathbf{n}$ & $\mathbf{\%}$ & Monthly Income & $\mathbf{n}$ & $\mathbf{\%}$ \\
\hline Primary School & 87 & 22.7 & No income & 48 & 12.5 \\
\hline High school & 112 & 29.2 & Minimum wage & 63 & 16.4 \\
\hline Graduate degree & 61 & 15.9 & TRY 2020-3000 & 104 & 27.1 \\
\hline Undergraduate & 113 & 29.4 & TRY 3001-4000 & 83 & 21.6 \\
\hline Master's degree & 11 & 2.9 & TRY 4001-5000 & 45 & 11.7 \\
\hline Place of Birth & $\mathbf{n}$ & $\mathbf{\%}$ & TRY 5001 and above & 41 & 10.7 \\
\hline Manavgat & 156 & 40.6 & Occupation & $\mathbf{n}$ & $\mathbf{\%}$ \\
\hline Other places & 228 & 59.4 & Student & 28 & 7.3 \\
\hline Works in tourism & $\mathbf{n}$ & $\mathbf{0}$ & Civil Servants & 102 & 26.6 \\
\hline Yes & 171 & 44.5 & Workers & 123 & 32.0 \\
\hline No & 213 & 55.5 & Tradesman & 29 & 7.6 \\
\hline Level of tourism & $\mathbf{n}$ & $\mathbf{\%}$ & Housewife & 17 & 4.4 \\
\hline Beginning & 25 & 6.5 & Retired & 14 & 3.6 \\
\hline Devolopment & 205 & 53.4 & Self-employment & 21 & 5.5 \\
\hline Maturity & 90 & 23.4 & No occupied & 6 & 1.5 \\
\hline Fall & 64 & 16.7 & Others & 44 & 11.5 \\
\hline Total & $\mathbf{3 8 4}$ & $\mathbf{1 0 0}$ & Total & $\mathbf{3 8 4}$ & $\mathbf{1 0 0}$ \\
\hline
\end{tabular}

\subsection{Reliability Analysis and Explanatory Factor Analyses (EFA)}

The reliability of the scale has been tested using the internal consistency method in the research. Accordingly, Cronbach's Alpha values of the scale have been examined and they have been subjected to explanatory factor analysis. As observed in Table 3; Cronbach's Alpha values $(\alpha)$ for each factor are 0.70 and above, which shows that the results are reliable (Bryne, 2010). Then, in the KMO sample adequacy test conducted to determine whether the data are suitable for factor analysis; the KMO value is 0.806 and the Bartlett test result $\left(x^{2}=3794.894\right)$ means $\mathrm{p}<0.05$, and the $\mathrm{KMO}$ value means that it has a sampling capability to provide a good level of correlation above 0.70 and that the data is suitable for factor analysis (Can, 2018). As a result of the explanatory factor analysis conducted, a statement belonging to the perceived economic positive effects factor, which has a contradictory load factor (Büyüköztürk, 2006), has been excluded from the analysis. As a result of the EFA after this statement has been removed from the data set, a six-factor structure consisting of 23 statements explaining $66,342 \%$ of the total variance has emerged. Likewise, explanatory factor analyzes have been made separately for the local community's satisfaction factor for the tourism development and the attitude factor for the tourism development. The satisfaction of the local community has been found as KMO .704 and the result of Bartlett test as $\left(x^{2}=402,633\right) \mathrm{p}<0.05$ and attitude towards the tourism development has been obtained as KMO .799 and Bartlett test as $\left(x^{2}=827,904\right)$. As a result of the EFA, it has been determined that the statements related to the satisfaction of the local community have been 


\section{JOURNAL OF TOURISM AND SERVICES}

Issue 21, volume 11, ISSN 1804-5650 (Online)

www.jots.cz

gathered under one factor, and the total variance level of these statements has been 73,104 , and the statements for the support for the tourism development have been gathered under one factor, and the total variance level of these statements is 73,417. As shown in Table 3, the factor loads of the statements forming the perceived effects of tourism are between .886 and .696 , the factor loads regarding the satisfaction of the local community are between .884 and .839 and the factor loads for the tourism development (support) are between .888 and .835 .

\subsection{Convergent and Discriminant Validity}

Within the scope of determining the reliability and validity of the study; CR, AVE, MSV, ASV and MaxR $(\mathrm{H})$ values have been examined (Table 2). CR (composite reliability) values are expected to be 0.70 and above and AVE (Average Variance Extracted) values are expected to be 0.50 and above in order to achieve convergent validity (Bryne, 2010). If the AVE value is higher than 0.50, it means that the variables associated with the factors are explained adequately, while the CR value is greater than 0.70, which means that the internal consistency of the factors is high (Fornell \& Larcker, 1981). The fact that MSV (Maximum Shared Variance) and ASV (Average Shared Variance) values are lower than AVE value, MaxR (H) (Maximum H Reliability) value is higher than CR value, and the square root of the AVE value of the latent variable with other variables is higher than the correlation values mean that the discriminant validity is provided (Hair et al., 2014).

Table 2. Convergent and Discriminant Validaty Values

\begin{tabular}{|l|l|l|l|l|l|l|l|l|l|l|l|l|l|}
\hline & CR & AVE & MSV & ASV & MaxR(H) & PSOC & PECO & PENV & SAT & ATT & NSOC & NECO & NENV \\
\hline PSOC & 0.752 & 0.504 & 0.359 & 0.169 & 0.759 & 0.710 & & & & & & & \\
\hline PECO & 0.875 & 0.638 & 0.333 & 0.169 & 0.915 & 0.577 & 0.799 & & & & & & \\
\hline PENV & 0.864 & 0.620 & 0.316 & 0.092 & 0,951 & 0.384 & 0.229 & 0.787 & & & & & \\
\hline SAT & 0.818 & 0.600 & 0.599 & 0.237 & 0.960 & 0.599 & 0.569 & 0.562 & 0.775 & & & & \\
\hline ATT & 0.872 & 0.633 & 0.599 & 0.205 & 0.970 & 0.552 & 0.558 & 0.345 & 0.774 & 0.796 & & & \\
\hline NSOC & 0.700 & 0.534 & 0.194 & 0.050 & 0.972 & -0.143 & -0.048 & 0.008 & -0.141 & -0.181 & 0.730 & & \\
\hline NECO & 0.770 & 0.533 & 0.169 & 0.072 & 0.975 & 0.138 & 0.396 & -0.059 & 0.161 & 0.231 & 0.278 & 0.730 & \\
\hline NENV & 0.812 & 0.524 & 0.194 & 0.058 & 0.978 & 0.050 & 0.056 & -0.083 & -0.120 & -0.120 & 0.441 & 0.411 & 0.724 \\
\hline
\end{tabular}

PSOC $=$ Positive Sociocultural Effects, $\mathrm{PECO}=$ Positive Economic Effects, PENV= Positive Environmental Effects, $\mathrm{SAT}=$ Satisfaction with Tourism Development, ATT $=$ Attitude towards the Development of Tourism, NSOC $=$ Negative Sociocultural Effects, NECO= Negative Economic Effects, NENV= Negative Environmental Effects, CR= Composite Reliability, AVE = Average Variance Extracted, MSV= Maximum Shared Variance, ASV= Average Shared Variance, Max $\mathrm{R}(\mathrm{H})=$ Maximum H Reliability and Diagonal values written in bold are square roots of AVE values.

Source: Authors own conception

When Table 2 is examined, it is determined that the lowest AVE value calculated for latent variables is 0.504 and the lowest $\mathrm{CR}$ value calculated is 0.700 , and it is understood that it provides the assumptions of its convergent validity. It is observed that MSV and ASV values of each latent variable that will enter the model for discriminant validity are smaller than AVE value and MaxR $(\mathrm{H})$ value is higher than CR value. In addition, it is understood that the correlation values between the square roots of the AVE value and the variables are acceptable, thereby ensuring the discriminant validity for all latent variables. Likewise, each of the correlation values between all variables included in the model is less than $r>0.85$ (Raykov \& Marcoulides, 2006), meaning that the dimensions in the model are separate structures and relationships between variables can be investigated.

\subsection{Measurement Model (Confirmatory Factor Analysis-CFA)}




\section{JOURNAL OF TOURISM AND SERVICES}

Issue 21, volume 11, ISSN 1804-5650 (Online)

www.jots.cz

As seen in Table 3, confirmatory factor analysis (CFA) has been performed to test the construct validity of the scales used in the measurement model. A wide range of fit indices can be viewed in CFA. For these fit indices, the Chi-Square Fit test $\left(\Delta \chi^{2} \leq 5\right)$, root mean square error of approximation (RMSEA $\leq 0.080$ ), Goodness of Fit Index (GFI, $\geq .80$ ), Comparative Fit Findex (CFI $\geq 0.90)$, Adjusted Goodness of Fit Index (AGFI, $\geq .80$ ) and incremental fix index (IFI $\geq 0.90$ ) values are often used, which are acceptable goodness of fit values (Schumacker \& Lomax, 2010).

Table 3. Explanatory factor analysis and measurement model values

\begin{tabular}{|c|c|c|c|c|c|c|c|c|}
\hline \multirow{2}{*}{\multicolumn{2}{|c|}{ Effects of Tourism }} & \multicolumn{4}{|c|}{ EFA Values } & \multicolumn{3}{|c|}{ CFA Values } \\
\hline & & \multirow{2}{*}{$\begin{array}{c}\begin{array}{c}\text { Factor } \\
\text { Loadings }\end{array} \\
.856\end{array}$} & \multirow{5}{*}{$\begin{array}{c}\begin{array}{c}\text { Variance } \\
\text { Extracted }\end{array} \\
20.550\end{array}$} & \multirow{5}{*}{$\begin{array}{c}\text { Eigenvalue } \\
4.727\end{array}$} & \multirow{5}{*}{$\begin{array}{c}\alpha \\
0.870\end{array}$} & \multirow{2}{*}{$\begin{array}{c}\begin{array}{c}\text { Standardize } \\
\text { Factor } \\
\text { Loadings }\end{array} \\
.864 \\
\end{array}$} & \multirow{2}{*}{$\begin{array}{l}\boldsymbol{t} \text { value } \\
13.671\end{array}$} & \multirow{2}{*}{$\begin{array}{c}\mathbf{p} \\
0.001\end{array}$} \\
\hline \multirow{4}{*}{$\begin{array}{l}\text { Positive } \\
\text { Economic } \\
\text { Effects }\end{array}$} & PECO3 & & & & & & & \\
\hline & PECO4 & .843 & & & & .807 & 15.590 & 0.001 \\
\hline & PECO2 & .797 & & & & .777 & 13.106 & 0.001 \\
\hline & PECO5 & .731 & & & & .741 & - & 0.001 \\
\hline \multirow{4}{*}{$\begin{array}{l}\text { Positive } \\
\text { Environmental } \\
\text { Effects }\end{array}$} & PENV2 & .886 & \multirow{4}{*}{17.405} & \multirow{4}{*}{4.003} & \multirow{4}{*}{0.850} & .887 & 11.466 & 0.001 \\
\hline & PENV3 & .854 & & & & .800 & 11.007 & 0.001 \\
\hline & \begin{tabular}{|l|} 
PENV1 \\
\end{tabular} & .840 & & & & .854 & 10.699 & 0.001 \\
\hline & PENV4 & .657 & & & & .569 & - & 0.001 \\
\hline \multirow{4}{*}{$\begin{array}{l}\text { Negative } \\
\text { Environmental } \\
\text { Effects }\end{array}$} & NENV2 & .858 & \multirow{4}{*}{10.590} & \multirow{4}{*}{2.436} & \multirow{4}{*}{0.827} & .718 & 12.200 & 0.001 \\
\hline & NENV3 & .807 & & & & .830 & 10.310 & 0.001 \\
\hline & NENV1 & .739 & & & & .570 & - & 0.001 \\
\hline & NENV4 & .728 & & & & .753 & 10.067 & 0.001 \\
\hline \multirow{4}{*}{$\begin{array}{l}\text { Positive } \\
\text { Sociocultural } \\
\text { Effects }\end{array}$} & PSOC2 & .773 & \multirow{4}{*}{7.131} & \multirow{4}{*}{1.640} & \multirow[b]{4}{*}{0.769} & .641 & 8.875 & 0.001 \\
\hline & PSOC1 & .757 & & & & - & - & - \\
\hline & PSOC4 & .710 & & & & .725 & - & 0.001 \\
\hline & PSOC3 & .636 & & & & .758 & 10.936 & 0.001 \\
\hline \multirow{4}{*}{$\begin{array}{l}\text { Negative } \\
\text { Sociocultural } \\
\text { Effects }\end{array}$} & NSOC2 & .780 & \multirow{4}{*}{5.884} & \multirow{4}{*}{1.353} & \multirow{4}{*}{0.733} & .756 & - & 0.001 \\
\hline & NSOC1 & .743 & & & & - & - & - \\
\hline & NSOC3 & .733 & & & & .704 & 7.004 & 0.001 \\
\hline & NSOC4 & .629 & & & & - & - & - \\
\hline Negative & NECO2 & .828 & \multirow{3}{*}{4.782} & & & .826 & 10.057 & 0.001 \\
\hline Economic & NECO1 & .794 & & & & .776 & 9.994 & 0.001 \\
\hline Effects & NECO3 & .661 & & 1.100 & 0.744 & .561 & - & 0.001 \\
\hline Satisfact & ion & $\begin{array}{c}\text { Factor } \\
\text { Loadings }\end{array}$ & $\begin{array}{l}\text { Variance } \\
\text { Extracted }\end{array}$ & Eigenvalue & $\alpha$ & $\begin{array}{c}\text { Standardize } \\
\text { Factor } \\
\text { Loadings } \\
\end{array}$ & $t$ value & $\mathrm{p}$ \\
\hline Satisfaction & SAT3 & .884 & & & & .804 & 15.247 & 0.001 \\
\hline with Tourism & SAT1 & .841 & 73.104 & 2.193 & 0.809 & .759 & - & 0.001 \\
\hline Development & SAT2 & .839 & & & & .760 & 14.437 & 0.001 \\
\hline Attitud & & $\begin{array}{c}\text { Factor } \\
\text { Loadings }\end{array}$ & $\begin{array}{l}\text { Variance } \\
\text { Extracted }\end{array}$ & Eigenvalue & $\alpha$ & $\begin{array}{c}\text { Standardize } \\
\text { Factor } \\
\text { Loadings } \\
\end{array}$ & $t$ value & $\mathrm{p}$ \\
\hline Attitude & ATT3 & .888 & & & & .883 & 20.605 & 0.001 \\
\hline towards the & ATT4 & .858 & 73417 & & & .848 & - & 0.001 \\
\hline development & ATT1 & .846 & 73.417 & 2.937 & 0.877 & .726 & 15.799 & 0.001 \\
\hline of Tourism & ATT2 & .835 & & & & .711 & 15.368 & 0.001 \\
\hline
\end{tabular}

Note: Extraction Method= Principal Component Analysis; Rotation Method: Varimax Rotation, Goodness-of-fit statistics of $\mathrm{CFA}=\Delta \chi 2=646.105 ; \mathrm{df}=290 ; \chi 2 / \mathrm{df}=2.228$; RMSEA=0.057; CFI=0.930; $\mathrm{GFI}=0.886 ; \mathrm{IFI}=0.931$.

Source: Authors own conception

During the measurement model (CFA), 1 statement of the perceived socio-cultural positive effects dimension and 2 statements of the perceived socio-cultural negative effects dimension have been excluded from the model, which made it difficult to assume the validity of combination and dissociation with the goodness of fit values of the model (Table 3). Goodness of fit values of the reconstructed measurement model are $\Delta \chi^{2}=646.105 ; \mathrm{df}=290 ; \chi^{2} / \mathrm{df}=2.228 ; \mathrm{RMSEA}=0.057$; CFI $=$ 


\section{JOURNAL OF TOURISM AND SERVICES}

Issue 21, volume 11, ISSN 1804-5650 (Online)

www.jots.cz

0.930; GFI=0.886; $\mathrm{IFI}=0.931$, which indicates that there is an acceptable goodness of fit (Hair et al., 2014), and as a result, the structural model and analysis can be tested.

\subsection{Testing the Structural Model}

After verification of the measurement model, the relationships between the variables used in the study have been tested through the structural equation model. Within the scope of structural equality model analysis, 7 hypotheses have been tested in order to reveal the effects of perceived positive and negative effects of tourism (socio-cultural, environmental and economic) on local community's satisfaction with tourism development and the effect of this satisfaction of the local community on the attitude towards the tourism development. In addition, in the research, three hypotheses formed under a basic hypothesis have been tested in order to determine whether the satisfaction of the local community towards tourism development has a moderator effect on gender, marital status and birthplace (demographic variables). The findings obtained as a result of the structural model realized for these purposes are reflected in Figure 2.

Figure 2. Structural Model Results

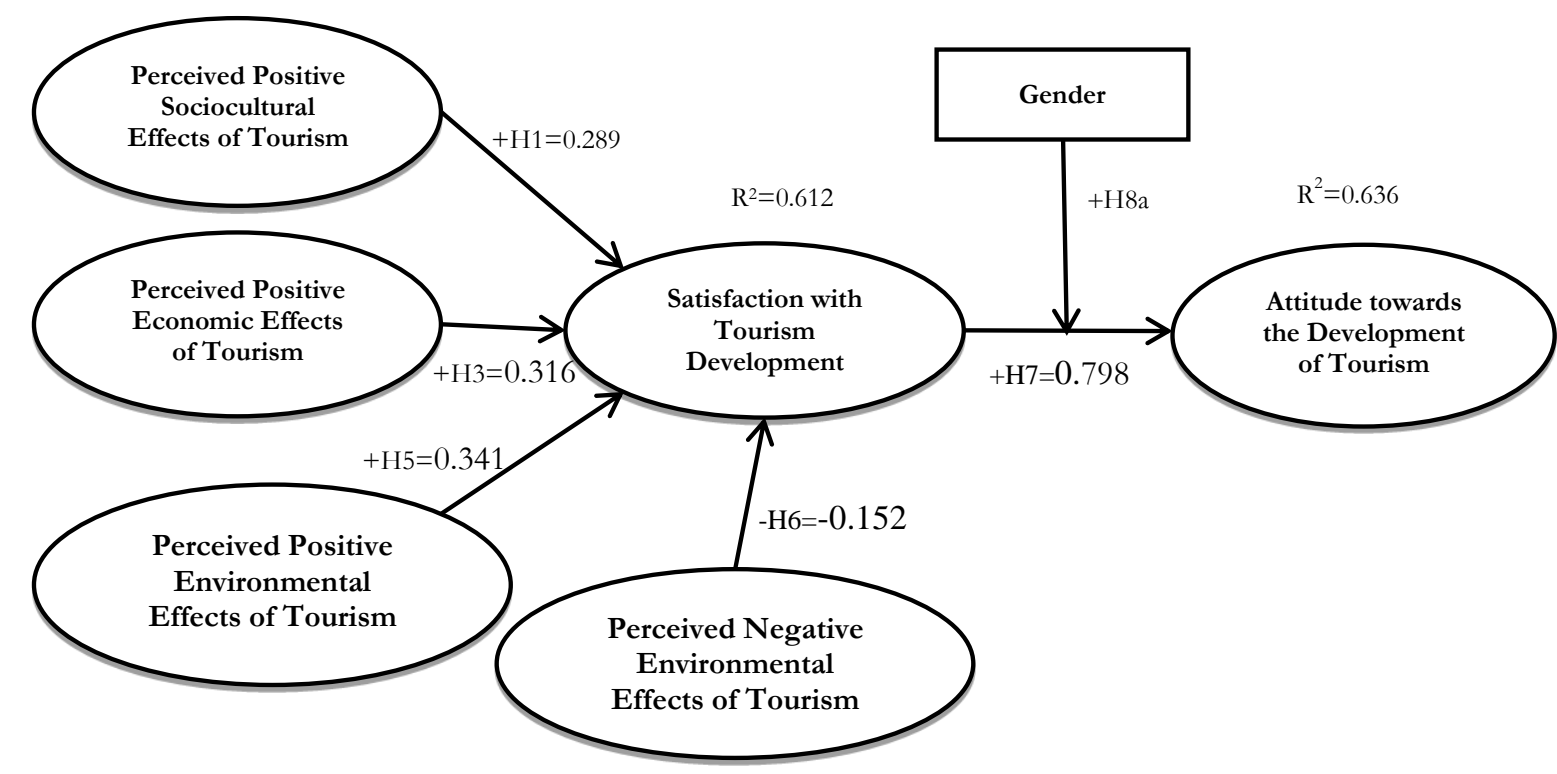

Source: Authors own conception

As observed in the path diagram in Figure 2; the socio-cultural, environmental and economic positive effects of tourism perceived by the local community are positively effective on the local community's satisfaction with tourism development and the economic negative effects of tourism perceived by the local community are negatively effective on the local community's satisfaction with tourism development. It is also stated that the economic negative effects perceived by the local community have an unexpectedly positive effect on the local community's satisfaction with tourism development. On the other hand, it is understood that it has a positive effect on the local community's satisfaction with tourism development and attitude towards the tourism development. Apart from all these statements, the model in Figure 2 shows the rate of variance explanation $61.2 \%\left(\mathrm{R}^{2}=0.612\right)$ of the local community's satisfaction with tourism development; the variance explanation rate regarding the attitude variable for the tourism development is $63.6 \%\left(\mathrm{R}^{2}=0.636\right)$. 


\section{JOURNAL OF TOURISM AND SERVICES}

Issue 21, volume 11, ISSN 1804-5650 (Online)

www.jots.cz

Upon reviewing the $t$ values obtained as a result of the structural model, it is observed that the $t$ values between the perceived socio-cultural, environmental and economic positive effects and perceived environmental negative effects and the local community's satisfaction with tourism development and the local community's satisfaction with tourism development and attitude are higher than 2.56 and at a significance level of $\mathrm{p}<0.001$ and that the $t$ values between the perceived sociocultural negative effects and the local community's satisfaction with tourism development are lower than 2.56 and at a significance level of $\mathrm{p}<0.05$. It has been determined that the $t$ values between the perceived economic negative effects of the local community and the local community's satisfaction with tourism development are much lower than 1.96 and not at a significance level of $\mathrm{p}<0.05$. It is understood that the path analysis of goodness of fit values for the significance of the structural model have acceptable goodness of fit values of $\Delta \chi 2=667.452 ; \mathrm{df}=296 ; \chi 2 / \mathrm{df}=2.255 ; \mathrm{RMSEA}=0.057$; CFI=0.927; GFI $=0.882$ (Hair et al., 2014).

Table 4. Findings Related to Path Analysis and Hypothesis Results

\begin{tabular}{|c|c|c|c|c|c|}
\hline Hypothesis & Path Analysis & $\begin{array}{l}\text { Standardize Factor } \\
\text { Loadings }\end{array}$ & $t$ values & $\mathrm{p}$ & Results \\
\hline$+\mathrm{H}_{1}$ & $\mathrm{PSOC} \rightarrow \mathrm{SAT}$ & 0.289 & 3.761 & $0.001^{* * *}$ & $\sqrt{ }$ \\
\hline$-\mathrm{H}_{2}$ & $\mathrm{NSOC} \rightarrow \mathrm{SAT}$ & -0.079 & -1.288 & 0.198 & $\mathrm{X}$ \\
\hline$+\mathrm{H}_{3}$ & $\mathrm{PECO} \rightarrow \mathrm{SAT}$ & 0.316 & 4.460 & $0.001 * * *$ & $\sqrt{ }$ \\
\hline$-\mathrm{H}_{4}$ & $\mathrm{NECO} \rightarrow \mathrm{SAT}$ & 0.140 & 2.258 & $0.024^{*}$ & $\mathrm{X}$ \\
\hline$+\mathrm{H}_{5}$ & $\mathrm{PENV} \rightarrow \mathrm{SAT}$ & 0.341 & 5.813 & $0.001^{* * *}$ & $\sqrt{ }$ \\
\hline$-\mathrm{H}_{6}$ & $\mathrm{NENV} \rightarrow \mathrm{SAT}$ & -0.152 & -2.520 & $0.012^{*}$ & $\sqrt{ }$ \\
\hline$+\mathrm{H}_{7}$ & SAT $\rightarrow$ ATT & 0.798 & 12.875 & $0.001^{* * *}$ & $\sqrt{ }$ \\
\hline
\end{tabular}

Source: Authors own conception

When the research model in Figure 2 and the hypothesis results in Table 4 are analyzed, the socio-cultural, environmental and economic positive effects of tourism perceived by the local community have a positive and significant effect on local community's satisfaction with tourism development $\left(\mathrm{H}_{1}: \beta=0.289, t=3.761, \mathrm{p}=0.001 ; \mathrm{H}_{3}: \beta=0.316, t=4.440, \mathrm{p}=0.001 ; \mathrm{H}_{5}: \beta=0.341, t=5.813\right.$, $\mathrm{p}=0.001)$. Therefore, the hypotheses $\mathrm{H}_{1}, \mathrm{H}_{3}$ and $\mathrm{H}_{5}$ developed as "The perceived socio-cultural, economic and environmental effects of tourism have a significant and positive effect on the satisfaction of the local community towards tourism development" are supported. It has been observed that the perceived negative environmental effects of tourism has a negative and significant effect on the local community's satisfaction with tourism development $\left(\mathrm{H}_{6}: \beta=-0.152, t=-2.520, \mathrm{p}=0,012\right)$ and accordingly, the hypothesis $\mathrm{H}_{6}$ developed as "The perceived environmental effects of tourism have a significant and negative impact on the satisfaction of the local community towards tourism development" has been supported. Meanwhile, it has been determined that the perceived socio-cultural and economic negative effects of tourism does not have a negative and significant effect on the local community's satisfaction with tourism development $\left(\mathrm{H}_{2}: \beta=-0.079\right.$, $t=-$ 1.288, $\left.\mathrm{p}=0.198 ; \mathrm{H}_{4}: \beta=0.140, t=-2.258, \mathrm{p}=0.024\right)$ From this point of view, the hypotheses $\mathrm{H}_{2}$ and $\mathrm{H}_{4}$ developed as "The perceived socio-cultural and economic effects of tourism have a significant and negative effect on the local community's satisfaction with tourism development" are not supported. In addition, it has been determined that the local community's satisfaction with tourism development has a positive and significant effect on the attitude towards tourism development $\left(\mathrm{H}_{7}: \beta=0.798, t=12.875, \mathrm{p}=0.001\right)$; therefore, the 


\section{JOURNAL OF TOURISM AND SERVICES}

Issue 21, volume 11, ISSN 1804-5650 (Online)

www.jots.cz

hypothesis $\mathrm{H}_{7}$ developed as "The satisfaction with tourism development has a significant and positive effect on attitude" is supported.

In the effect of the local community's satisfaction with tourism development on the attitude, a moderator effect analysis has been performed according to demographic variables such as gender, marital status and birthplace. Prior to the analysis, the value of satisfaction of the local population, which is the estimated variable, to the tourism development has been standardized. As observed in Table 5; as a result of the path analysis with the observed variables, Slope difference test has been performed in order to see whether the differences between the regression coefficients $(\beta)$ occurring according to categorical variables are significant and the results are displayed below.

Table 5. Slope Differences Tests

\begin{tabular}{|c|c|c|c|c|c|c|}
\hline & \multicolumn{2}{|c|}{ Gender } & \multicolumn{2}{|c|}{ Marital Status } & \multicolumn{2}{|c|}{ Place of Birth } \\
\hline & Male & Female & Married & Single & Manavgat & Others \\
\hline Number of Samples & 244 & 140 & 263 & 121 & 156 & 228 \\
\hline Regression Coefficients $(\beta)$ & 0.621 & 0.436 & 0.549 & 0.577 & 0.599 & 0.512 \\
\hline Standard Error & 0.040 & 0.054 & 0.039 & 0.056 & 0.049 & 0.043 \\
\hline$t$ values & \multicolumn{2}{|c|}{2.777} & \multicolumn{2}{|c|}{0.407} & \multicolumn{2}{|c|}{1.323} \\
\hline $\mathrm{p}$ values $\left(*_{\mathrm{p}}<0.01\right)$ & \multicolumn{2}{|c|}{$0.006^{*}$} & \multicolumn{2}{|c|}{0.684} & \multicolumn{2}{|c|}{0.187} \\
\hline
\end{tabular}

Source: Authors own conception

Figure 3. Graphical Display of the Moderator Effect of Gender

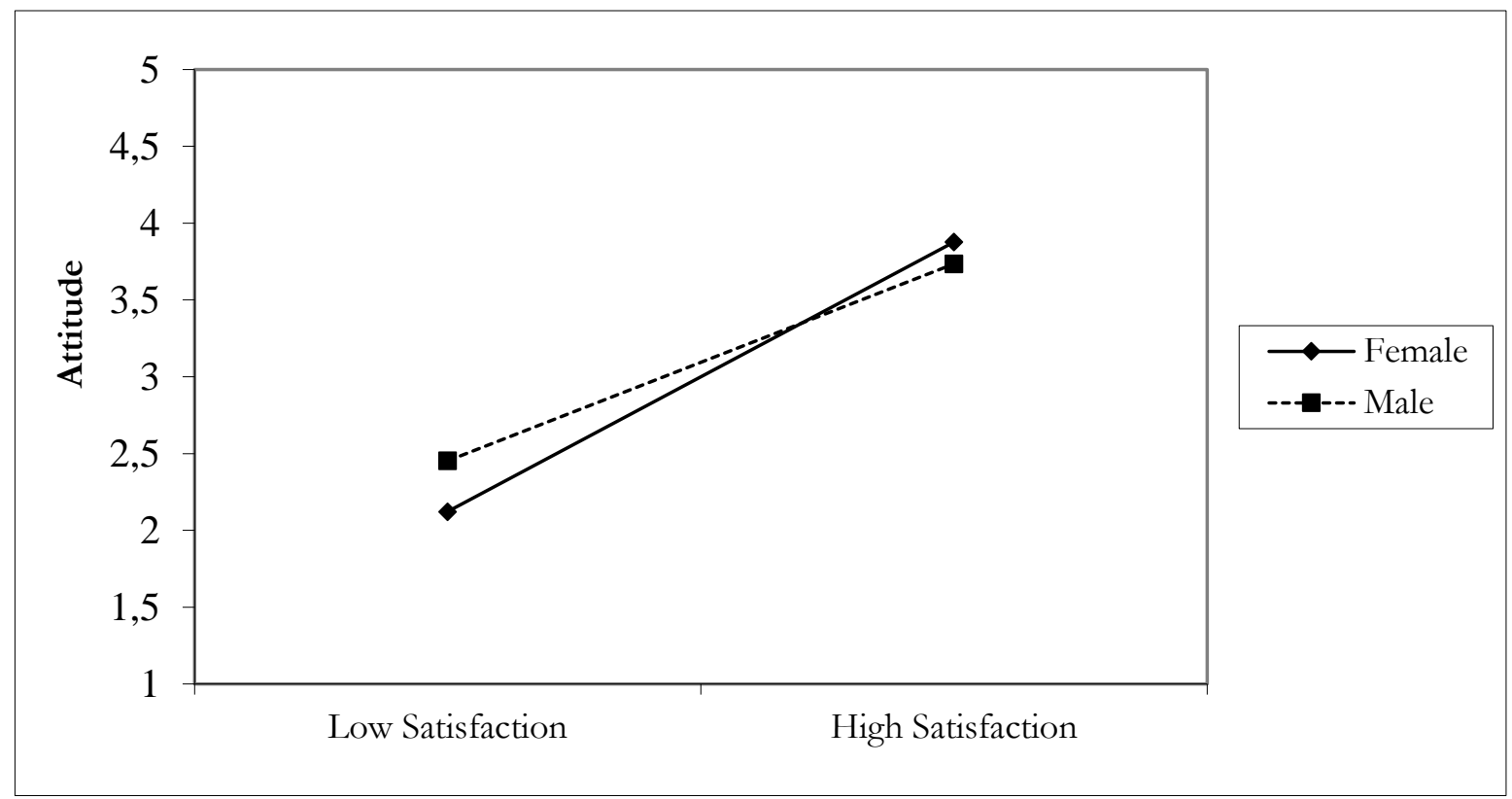

Source: Authors own conception

According to these results in Table 5; it has been revealed that gender (Male: $\beta=0.621$, Female: $\beta=0.436, t=2.777, p=0.006$ ) has a moderator effect on the effect of local community's satisfaction with tourism development on the attitude towards tourism development. In this case, the hypothesis $\mathrm{H}_{8 \mathrm{a}}$ developed as "Gender has a moderating effect on the relationship between satisfaction and attitude towards tourism 


\section{JOURNAL OF TOURISM AND SERVICES}

Issue 21, volume 11, ISSN 1804-5650 (Online)

www.jots.cz

development" is supported. Meanwhile, it has been determined that the marital status (Married: $\beta=0.549$, Single: $\beta=0.577, t=0.477, p=0.684$ ) and place of birth (Manavgat: $\beta=0.599$, Other: $\beta=0.512, t=1.323$, $\mathrm{p}=0.187$ ) does not have a moderator effect on the effect of local community's satisfaction with tourism development on attitude. Therefore, the hypothesis $\mathrm{H}_{8 \mathrm{~b}}$ developed as "Marital status has a moderating effect on the relationship between satisfaction and attitude towards tourism development" is not supported. Similarly, the hypothesis $\mathrm{H}_{8 \mathrm{c}}$ developed as "The place of birth has a moderating effect on the relationship between satisfaction with tourism development and attitude" is not supported.

In order to determine the form and direction of the effect of local community's satisfaction with tourism development on attitude, the views of men and women about their attitudes towards the tourism development are graphically given in Figure 3. Graph drawing for binary categorical variable has been analyzed with Slope test. As a result of the slope test, the relationship between local community's satisfaction with tourism development and attitude is positive for both men and women. Consequently, when men's satisfaction with tourism development is low, it is observed that they have more attitudes towards tourism development compared to women. According to this result, it can be said that tourism professionals can increase their attitudes towards the tourism development by gender, considering the characteristics of the local community's satisfaction with tourism development.

\section{Discussion, Conclusion, Limitations and Recommendations for Tourism Stakeholders.}

As an important part of social life in order to escape from the routine of daily life, to fulfill the sense of curiosity or to provide social status, tourism has multidimensional and dynamic effects on individuals who demand and provide service. These effects can lead to consequences such as social harmony or conflict. Multidimensional effects such as socio-cultural, economic and environmental caused by tourism also encourage research in this area of the sector (Özyurt, 2018). Sustainable development in tourism can be achieved by establishing a balance between socio-cultural, economic and environmental impacts as much as possible. Therefore, understanding the potential of the effects of tourism in the development process is the basic and logical assumption of sustainable tourism planning. Consequently, it may be an appropriate basis for reducing negative effects on tourism and improving positive effects (Nematpour \& Faraji, 2019). If the local community is made a part of this process while planning tourism, the local community will feel empowered and will be more likely to perceive the benefits of tourism, potentially developing pro-tourism development behavior (Riberio et al., 2017: 531). In general, it is understood that the competition for residents, tourists and investments among the cities that are interested in the development of tourism inflows has increased significantly (Herget et al. 2015, p.125).

In order to determine the effect of perceived socio-cultural, economic and environmental positive and negative effects of tourism on the satisfaction with tourism development in Manavgat and the effects of the satisfaction with tourism development on the attitude towards the support of tourism development of the local community, and in order to test the moderator effect of the gender, marital status and birthplace among the demographic variables in this relationship; eight hypotheses have been developed based on the literature and six have been supported.

In the study, first of all, explanatory factor analyses, confirmatory factor analysis, path analyses and slope difference tests have been conducted to determine the perceived effects of tourism of the local community. According to the research findings; It has been determined that the socio-cultural, environmental and economic positive effects of tourism perceived by the local community increase the local community's satisfaction with tourism development. Similarly, as a result of the research conducted by Nunkoo \& Ramkissoon (2007, p.143) in Mauritius, they have stated that local community 


\section{JOURNAL OF TOURISM AND SERVICES}

Issue 21, volume 11, ISSN 1804-5650 (Online)

www.jots.cz

generally support tourism, but they are worried about the impact of tourism on the image of the region, and the benefits of tourism should be increased before the number of tourists in planning tourism.

Riberio et al. (2017) have stated that economic factors have a direct impact on local community's pro-tourism development behavior. They have also noted that tourism should be planned in a sustainable way to reflect the economic benefits of people and society, and should encourage the local economy. Boley et al. (2014, p.47) state that local community expressing their opinions about tourism can make the perceived effects of tourism more positive and eventually they will increase their likelihood of supporting tourism.

As a result of the research conducted on the effect of non-economic factors on sustainable tourism development of the residents, Eslami et al. (2018) have found that the perceived environmental effects of tourism as a non-economic factor do not affect the living spaces of the residents; however, it is effective on their means of entertainment. In addition, the perceived socio-cultural effects of tourism both affect the satisfaction of the living people and entertainment opportunities, and this is reflected in the overall quality of life, and as a result, the overall quality of life satisfaction has significantly affected the support of the residents in sustainable tourism development.

It has been determined that perceived environmental negative effects of local community reduce the local community's satisfaction with tourism development. It has been revealed that perceived socio-cultural negative effects do not affect local community's satisfaction with tourism development. Contrary to the hypothesis, a different result has been obtained that the perceived economic negative effects of tourism increase the satisfaction of the local community.

Another result of the study is that local community's satisfaction with tourism development increases the attitude towards the tourism development positively. As a matter of fact, this result is supported by the previous study by Ekici \& Çizel (2014). Ekici \& Çizel (2014, p.84-85) have stated that the increase in the benefit of the local community from tourism increases the satisfaction and the increase in satisfaction increases the support given to tourism. Likewise, Kim et al. (2013, p.537) have mentioned that local community are affected economically, socioculturally and environmentally by tourism and that these effects affect their habitats. They have stated that economic impact significantly predicts the sense of material well-being, social influence is the sense of social welfare, and cultural effect is emotional well-being. In addition, negative perceptions about environmental impact significantly predict the local community's sense of health and safety.

The important result that distinguishes the study from all other studies is that gender has a moderating effect on the relationship local community's satisfaction with tourism development and the attitude towards the tourism development. This moderator effect is positive on both men and women. However, in the case of men's low satisfaction with tourism development, they have attitudes towards more tourism development compared to women, while with high satisfaction, they have less attitudes towards the tourism development compared to women. It has been determined that marital status and birthplace do not have a moderator effect in the relationship between local community's satisfaction with tourism development and the attitude towards tourism development.

The effects of tourism vary according to demographic variables. The reactions of the local community are very important especially in regions with a developed tourism such as Manavgat. According to the results revealed in the study, if the satisfaction of the local community is low, the attitudes of men towards the tourism development are lower.

Undoubtedly, public institutions, tourism professionals, non-governmental organizations and related individuals in Manavgat should note that that they can increase their attitudes towards the tourism development with the gender factor while considering the effects of tourism on the region and the characteristics of the local community's satisfaction with tourism development. Considering that the effects of tourism may have effects not only on gender but also on many different variables, studies in which these effects can be tested can be conducted in the future. This study has several limitations. First, this study focuses on the economic, socio-cultural and environmental positive-negative effects of 


\section{JOURNAL OF TOURISM AND SERVICES}

Issue 21, volume 11, ISSN 1804-5650 (Online)

www.jots.cz

tourism. Secondly, this study is limited only to the opinions of the sample living in Manavgat district and included in this study and the questions included in the research questionnaire.

\section{References}

1. Ak, M. M. (2019). Manavgat ilçesinin ekonomik coğrafyası. Master’s Degree Thesis, Ondokuz Mayis University, Samsun, Turkey.

2. Alaeddinoğlu, F. (2008). Sivas kentinde halkın turiste ve turizme bakışı. Uluslararası İnsan Bilimleri Dergisi, 5(2), 1-23.

3. Almeida-García, F. (2018). Analysis of tourism policy in a developing country: The case of Morocco. Journal of Policy Research in Tourism, Leisure and Events, 10(1), 48-68.

4. Andereck, K.L. \& Vogt, C. A. (2000). The relationship between Residents' attitudes toward tourism and tourism development options, Journal of Travel Research, 39(1), 27-36.

5. Androniceanu, A. (2019). The social sustainability of smart cities: urban technological innovation, big data management, and the cognitive internet of things. Geopolitics, History, and International Relations 11(1), 110-115.

6. Androniceanu, A., Tvaronavičienè, M. (2019). Developing a holistic system for social assistance services based on effective and sustainable partnerships. Administratie si Management Public, 33, 103-118.

7. Anuar, A.N., Ridzuan, F.H., Jaini, N., Sulaiman, F.C., \& Hashim, N.I. (2019). The impact of overtourism towards local community in heritage city, Journal of Tourism \& Hospitality, 8(3), 406.

8. Ayazlar, G. (2016). Yerel halkın turizmin etkilerine yönelik tutumlarını anlamak: Yerel halkın bölge imajı ve turizme desteği, Uluslararası Sosyal Araștırmalar Dergisi, 9(43), 2538-2547.

9. Boğan, E. \& Sarışık, M. (2016). Yerel halkın turizm faaliyetine yönelik görüş ve algılamalarının belirlenmesi üzerine Alanya'da bir araştırma, Kastamonu Üniversitesi İktisadi ve İdari Bilimler Fakültesi Dergisi, 12, 325-342.

10. Boley, B. B., McGehee, N. G., Perdue, R. P. \&Long, P. (2014). Empowerment and resident attitudes toward tourism: Strengthening the theoretical foundation through a weberian lens, Annals of Tourism Research, 49, 33-50.

11. Brankov, J., Penjišević, I., B. Ćurčić, N. \& Živanović, B. (2019). Tourism as a factor of regional development: community perceptions and potential bank support in the Kopaonik National Park (Serbia), Sustainability, 11, 6507.

12. Bryne, M. B. (2010). Structural equation modeling with AMOS (Second Edition). New Jersey, USA: Lawrence Erbaum Associates Publisher.

13. Butler, R. W. (1980). The concept of tourism area cycle of evolution: Implications for management of resources, Canadian Geographer, 24(1), 5-12.

14. Büyüköztürk, Ş. (2006). Sosyal bilimler için veri analizi el kitabı. Ankara: Pegem Akademi.

15. Can, A. (2018). SPSS ile bilimsel araştırma sürecinde nicel veri analizi. 6. Baskı, Pegem Akademi, Ankara.

16. Manavgat Chamber of Commerce and Industry, (2016). Turizm ve Manavgat için acil önlemler raporu. Retrieved May 22, 2020 from https://www.matso.org.tr/images/raporlar/turizm-vemanavgat-icin-acil-onlemler-raporu.pdf. 


\section{JOURNAL OF TOURISM AND SERVICES}

Issue 21, volume 11, ISSN 1804-5650 (Online)

www.jots.cz

17. Dkhili, H. (2018). Environmental performance and institutions quality: evidence from developed and developing countries. Marketing and Management of Innovations, (3), 333-344.

18. Doxey, G. V. (1975). A causation theory of visitor resident irritants, methodology and research inferences. Paper presented in the Sixth annual conference proceedings of the Travel Research Association, San Diego, TX; 195-198.

19. Ekici, R. \& Çizel, B. (2014). Yerel halkın turizm gelişimi desteğine ilişkin tutumlarının destinasyonların gelişme düzeylerine göre farkll1ıkları, Seyahat ve Otel Issletmeciliği Dergisi, 11(3), 7387.

20. Eslami, S., Khalifah, Z., Mardani, A., \& Streimikiene, D. (2018). Impact of noneconomic factors on residents' support for sustainable tourism development in Langkawi Island, Malaysia. Economics and Sociology, 11(4), 181-197.

21. Fila, M., Schwarczová, L.; \& Mura, L. (2015). Citizen satisfaction survey as a tool of citizen relationship management of local government in Slovakia. Serbian Journal of Management 10(1): 117-129.

22. Faulkner, B. \& Tideswell, C. (1997). A framework for monitoring community impacts of tourism, Journal of Sustainable Tourism, 5(1), 3-28.

23. Filiz, A. \& Yılmaz, Ö. D. (2017). Turizm gelişim yaklaşımları kapsamında yerel halkın turizme yönelik alg1 ve tutumları: Mazı Köyü-Türkbükü karşılaştırmalı analizi, Hitit Üniversitesi Sosyal Bilimler Enstitüsü Dergisi, 10(2), 1799-1824.

24. Fornell, C. \& Larcker, D. F. (1981). Evaluating structural equation models with unobservable variables and measurement error, Journal of Marketing Research, 18(1), 39-50.

25. Gozgor, G., Demir, E. (2018). The Effects of Economic Policy Uncertainty on Outbound Travel Expenditures. Journal of Competitiveness, 10(3), 5-15.

26. Gündüz, S. (2018). Yerel halkın turizm alg1sını belirlemeye yönelik alternatif bir ölçek geliştirme: Karataş destinasyonu örneği, Journal of Yasar University, 13(52), 343-357.

27. Güneş, E. \& Alagöz, G. (2018). Yerel halkın turizm alg1sı: Erzincan'da bir araştırma, Iğder Üniversitesi Sosyal Bilimler Dergisi, 15, 409-442.

28. Hair, J., Black, W., Babin, B. \& Anderson, R. (2014). Multivariate data ANALYSIS (7th Edition). Pearson New International Edition.

29. Hançer, Ş. \& Mancı, A. R. (2017). Yerel halkın turizme bakış açısının belirlenmesi üzerine bir araştırma: Diyarbakır örneği, Journal of Tourism and Gastronomy Studies, 5(4), 70-91.

30. Hecht, B., Valaskova, K., Kral, P., \& Rowland, Z. (2019). The Digital Governance of Smart City Networks: Information Technology-driven Economy, Citizen-centered Big Data, and Sustainable Urban Development, Geopolitics, History, and International Relations, 11(1), 128-133.

31. Herget, J., Petrů, Z. \& Abrhám, J. (2015). City branding and its economic impacts on tourism, Economics and Sociology, 8(1), 119-126.

32. Hong Long, P. (2012). Tourism impacts and support for tourism development in Ha Long Bay, Vietnam: An examination of residents' perceptions, Asian Social Science, 8,8.

33. Horecký, J., Blažek, M. (2019). Dependent work and internship. Central European Journal of Labour Law and Personnel Management, 2 (2), 7-20.

34. Jurowski, C., Uysal, M. \& Williams, D. R. (1997). A theoretical analysis of host community resident reaction to tourism, Journal of Travel Research, 36(2), 3-11. 


\section{JOURNAL OF TOURISM AND SERVICES}

Issue 21, volume 11, ISSN 1804-5650 (Online)

www.jots.cz

35. Kalaycı, Ş. (2008). SPSS uygulamalı çok değişkenli istatistik teknikleri. (3.Baskı), Ankara: Asil Yayın Dağıtım.

36. Karakaş, A. \& Şengün, H. İ. (2017). Yerel halkın turizm faaliyetlerine yönelik tutumları, Bartın Üniversitesi İ.I.B.F. Dergisi, 8(15), 183-202.

37. Kennell, J. (2016). Carrying Capacity. In: Jafari, J. ve Xiao, H. (Eds). Encyclopedia of Tourism. Springer International Publishing, Switzerland, 133-135.

38. Kim, K., Uysal, M. \& Sirgy, M. J. (2013). How does tourism in a community impact the quality of life of community residents?, Tourism Management, 36, 527-540.

39. Ko, D.W. \& Stewart, W. P. (2002). A structural equation model of residents attitudes for tourism development, Tourism Management, 23, 521-530.

40. Kozak, N., Kozak, M. A. \& Kozak, M. (2015). Genel turizm. Yenilenmiş 17. Baskı, Detay Yayıncilik: Ankara.

41. Kuvan, Y. \& Akan, P. (2005). Residents' attitudes toward general and forest-related impacts of tourism: The case of Belek, Antalya, Tourism Management, 26, 691-706.

42. Lim, J.-E. \& Lee, H.R. (2020). Living as residents in a tourist destination: A phenomenological approach, Sustainability, 12, 1836.

43. Masharsky, A., Azarenkova, G., Oryekhova, K., \& Yavorsky, S. (2018). Anti-crisis financial management on energy enterprises as a precondition of innovative conversion of the energy industry: case of Ukraine. Marketing and Management of Innovations, (3), 345-354.

44. Meyer, D.F., Masehla, T.M., Kot, S. (2017). The relationship between economic growth and economic development: A regional assessment in South Africa. Journal of Advanced Research in Law and Economics, 8 (4), 1377-1385.

45. Nematpour, M. \& Faraji, A. (2019). Structural analysis of the tourism impacts in the form of future study in developing countries (case study: Iran), Journal of Tourism Futures, 5(3), 259-282.

46. Nunkoo, R. \& Ramkissoon, H. (2007). Residents' perceptions of the socio-cultural impact of tourism in Mauritius, Anatolia, 18(1), 138-145.

47. Olcay, A. \& Araboğa, Y. (2018). Bitlis ilinin turizm potansiyeli ve yerel halkın turizm olgusuna bakış açısı, Uluslararası Sosyal Araştırmalar Dergisi, 11(57), 946-961.

48. Öztürk, A. B., Özer, Ö., \& Çalışkan, U. (2015), The relationship between local residents' perceptions of tourism and their happiness: A case of Kusadasi, Turkey, Tourism Review, 70(3), 232-242.

49. Özyurt, P. M. (2018). Turizm gelişiminin yerel halkin bireysel ve toplumsal yaşam kalitesi üzerine etkilerinin incelenmesi. Doctoral Thesis, Akdeniz University, Antalya.

50. Raykov, T. \& Marcoulides, A. G. (2006). A first course instructural equation modeling (2th Edition). New Jersey, USA: Lawrence Erlbaum Inc.

51. Riberio, M. A., Pinto, P., Silva, J. A. \& Woosnam, K. M. (2017). Residents' attitudes and the adoption of pro-tourism behaviours: The case of developing Island Countries, Tourism Management, 61, 523-537.

52. Schumacker, R. E \& Lomax, R. G. (2010). A beginner's guide to structural equation modeling. New York: Taylor \& Francis Group, USA.

53. Snaith, T. \& Haley, A. (1999). Residents' opinions of tourism development in the historic city of York, England, Tourism Management, 20, 595-603. 


\section{JOURNAL OF TOURISM AND SERVICES}

Issue 21, volume 11, ISSN 1804-5650 (Online)

www.jots.cz

54. Szczepańska-Woszczyna, K., Kurowska-Pysz, J. (2016). Sustainable business development through leadership in SMEs. Engineering Management in Production and Services, 8(3), 57-69.

55. Szromek, A., Kruczek, Z. \& Walas, B. (2020). The Attitude of Tourist Destination Residents towards the Effects of Overtourism-Kraków Case Study, Sustainability, 12, 228.

56. Tayfun, A. (2002). Turist yerli halk etkileşimi üzerine bir araştırma, Gą̧i Üniversitesi Ticaret ve Turizm Ë̈itim Fakültesi Dergisi, 1, 1-12.

57. Thetsane, R. M. (2019). Local community participation in tourism development: The case of Katse Villages in Lesotho, Athens Journal of Tourism, 6(2), 123-140.

58. Tuna, M. (2007). Turizm, çevre ve toplum: Marmaris öneği. Detay Yayıncılık: Ankara.

59. Türker, N., Selçuk, Ş. \& Özyıldırım, A. (2016). Turizmin yerel halkın yaşam kalitesi üzerine etkisi: Safranbolu örneği, Karabük Üniversitesi Sosyal Bilimler Enstitüsü Dergisi, 6(1), 1-13.

60. Vargas-Sanchez, A., Plaza-Mejia, M.A., \& Porras-Bueno, N. (2009). Residents' attitudes towards tourism devolopment in the spanish province of Huelva, Narodnostopanski Arhiv, International Edition, 31-63.

61. Wang, J., Huang, X., Gong, Z. \& Cao, K. (2020). Dynamic assessment of tourism carrying capacity and its impacts on tourism economic growth in urban tourism destinations in China, Journal of Destination Marketing \& Management, 15.

62. Wang, Y., Pfister, E.R. \& Morais, B.D. (2006). Residents' attitudes toward tourism development: A case study of Washington, Nc, Paper presented at the Northeastern Recreation Research Symposium, 411-418.

63. Yazıcıŏlu, Y. \& Erdoğan, S. (2004). SPSS uygulamalı bilimsel araştırma yöntemleri. Ankara: Detay Yayıncilik.

\section{Brief description of Authors:}

\section{Abdullah USLU}

Assistant professor

Department of tourism management

Manavgat Faculty of Tourism

Akdeniz University, Turkey

Emek Mah. Piyade Er Fikret Karamusaoğlu Cd. No:156, 07600,

Manavgat/Antalya/Turkey

$+902427427025$

auslu@akdeniz.edu.tr

Abdullah USLU is an assistant professor in the Faculty of Manavgat Tourism at Akdeniz University. His main research areas are tourism marketing, tourist behaviour, destination marketing and management, service quality and sustainable tourism.

\section{Gürkan ALAGÖZ}

Assistant Professor

Hotel, Restaurant, and Catering Services

Vocational School of Tourism and Hotel Management

Erzincan Binali Yıldırım University

Erzincan/Turkey 
+904462251702

Gürkan ALAGÖZ is an Assistant Professor at Erzincan Binali Yıldırım University Vocational School of Tourism and Hotel Management. His research interests are organizational change, leadership, destination marketing and management, tourism education, cultural tourism and sustainable tourism.

\section{Erkan GÜNEŞ}

Assistant Professor

Department of Travel-Tourism and Entertainment Services

Vocational School of Tourism and Hotel Management

Erzincan Binali Yıldırım University

Erzincan/Turkey

+904462251702

Erkan GÜNEŞ is an Assistant Professor at Erzincan Binali Yıldırım University Vocational School of Tourism and Hotel Management. His research interests are destination marketing and management, destination quality, tourism education, cultural heritage tourism and sustainable tourism. 
JOURNAL OF TOURISM AND SERVICES

Issue 21, volume 11, ISSN 1804-5650 (Online)

www.jots.cz

\section{Appendix}

\begin{tabular}{|c|c|}
\hline & Appendix \\
\hline $\mathbf{P e}$ & eived Negative-Positive Socio-Cultural Effects of Tourism \\
\hline 1 & It ensures the development of cultural activities. \\
\hline 2 & It contributes to the cultural development of the local people. \\
\hline 3 & It increases the quality of life of the local people. \\
\hline 4 & It increases the leisure free time opportunities of local people. \\
\hline 5 & It negatively affects the attitudes and behaviors of the local people. \\
\hline 6 & It causes the cultural values to disappear. \\
\hline 7 & It makes it difficult for local people to access tourist attractions. \\
\hline 8 & It causes social problems such as crime, prostitution and drugs. \\
\hline $\mathbf{P e}$ & eived Positive-Negative Economic Effects of Tourism \\
\hline 9 & It provides the production of traditional products. \\
\hline 10 & It provides economic gain. \\
\hline 11 & It supports the local economy. \\
\hline 12 & It creates new job opportunities for local people. \\
\hline 13 & It provides more investments to the region. \\
\hline 14 & It increases the prices of products and services in the region. \\
\hline 15 & It causes costly life in the region. \\
\hline 16 & It creates economic inequality among local people. \\
\hline $\mathbf{P e}$ & eived Positive-Negative Environmental Effects of Tourism \\
\hline 17 & It supports the protection and development of the natural environment. \\
\hline 18 & It improves environmental quality for future generations. \\
\hline 19 & It increases environmental awareness. \\
\hline 20 & It promotes the protection of historical buildings and structures. \\
\hline 21 & It causes environmental pollution (soil, air, water). \\
\hline 22 & It affects nature (plants, animals, ecosystem) negatively. \\
\hline 23 & It causes conurbation. \\
\hline 24 & It creates problems such as crowding, noise pollution, traffic congestion. \\
\hline Att & ude Towards Tourism Development \\
\hline 25 & Efforts should be made for the further development of tourism. \\
\hline 26 & Tourism investments should continue increasingly. \\
\hline 27 & I support tourism development. \\
\hline 28 & Tourism should continue to be a part of our society. \\
\hline Sat & faction with Tourism Development \\
\hline 29 & I am satisfied with the environmental change and development created by tourism. \\
\hline 30 & I am satisfied with the economic developments that tourism provides to our region. \\
\hline 31 & I am satisfied with the social opportunities and opportunities that tourism provides to our region. \\
\hline
\end{tabular}

